\title{
EKSKLUSI SOSIAL PADA MASYARAKAT PETANI
}

\author{
Desi Yunita ${ }^{1}$, Bintarsih Sekarningrum ${ }^{2}$ \\ Program Studi Sosiologi, Fakultas Ilmu Sosial dan Ilmu Politik, Universitas Padjadjaran \\ desi.yunita@unpad.ac.id
}

\begin{abstract}
ABSTRAK
Konsep eksklusi sosial yang digunakan oleh para sosiolog barat, saat ini juga telah berkembang dan menjadi kajian keilmuan sosial di Indonesia. Pertumbuhan penduduk dan kebijakan pembangunan yang dikembangkan oleh pemerintah di daerah pedesaan telah menimbulkan perubahan pada masyarakat petani. Artikel ini berfokus pada perubahan-perubahan yang menjadi pendorong terjadinya eksklusi sosial pada masyarakat petani, dan memperlihatkan bentuk-bentuk eksklusi sosial apa saja yang terjadi pada masyarakat petani khususnya di wilayah Jawa Barat. Hasil penelitian memperlihatkan bahwa fenomena perkembangan wilayah pedesaan berperan dalam mendorong terjadinya eksklusi pada pekerjaan, kesehatan, pendidikan, yang dipengaruhi oleh terjadinya alih fungsi lahan pertanian.
\end{abstract}

Kata Kunci : eksklusi sosial, petani, kebijakan

\begin{abstract}
The concept of social exclusion used by western sociologists, now also has developed and become a study of social science in Indonesia. Population growth and development policies developed by governments in rural areas have led to changes in farming communities. This article focuses on the changes that drive social exclusion on peasant societies, and shows what forms of social exclusion are occurring in farming communities especially in West Java. The results show that the phenomenon of rural development plays a role in encouraging the exclusion of work, health, education, which is influenced by the conversion of agricultural land.
\end{abstract}

Keywords : social exclusion, farmers, policy

2. Program Studi Sosiologi, Fakultas Ilmu Sosial dan Ilmu Politik, Universitas Padjadjaran Bintarsih.sekarningrum@unpad.ac.id 


\section{PENDAHULUAN}

Pertanian merupakan sektor yang berkontribusi penting dalam pembangunan nasional Indonesia terutama perannya dalam pembentukan PDB, penyerapan tenaga kerja, dan sumber pendapatan masyarakat, serta perannya dalam memproduksi produk pertanian untuk penyediaan pangan, pakan, bahan baku industri dan ekspor.

Bappenas dalam analisisnya menyebutkan bahwa terjadi peningkatan PDB sektor pertanian di tahun 2011. Akan tetapi, keberhasilan trasnformasi ekonomi di banyak sektor selain pertanian yang terjadi di Indonesia mendorong kontribusi sektor pertanian terhadap pembentukan PDB total Indonesia mengalami penurunan. Hal tersebut dapat di duga terjadi karena adanya perubahan pada struktur masyarakat petani itu sendiri. Baik perubahan yang dipengaruhi oleh terjadinya perubahan fungsi lahan pertanian, maupun terjadinya peralihan profesi dari petani ke sektor lainnya.

Meskipun selama ini dikenal sebagai salah satu wilayah penghasil beras di wilayah Provinsi Jawa Barat, saat ini Kabupaten Sumedang juga terus mengalami perkembangan hal tersebut salah satunya dapat dilihat dari adanya wilayah yang diperuntukkkan sebagai kawasan industri yaitu kecamatan Jatinangor dan Kecamatan Cimanggung. Dimana di Kecamatan Jatinangor terdapat 9 unit industri besar, dan 22 unit di Kecamatan Cimanggung.

Kecamatan Jatinangor juga dikenal sebagai kawasan pendidikan tinggi (KPT) yang penunjukannya berdasarkan surat keputusan dari Gubernur Jawa Barat. Dimana awalnya terdapat empat universitas yang dipusatkan di wilayah ini yaitu Universitas Padjadjaran, Institut Manajemen Koperasi Indonesia, Institut Pemerintahan Dalam Negeri (IPDN) dan juga Universitas Winaya Mukti yang belakangan lahannya dipergunakan oleh Institut Teknologi Bandung. Keberadaan empat Universitas ternama tersebut telah menjadi daya tarik dan mendorong bertumbuhnya kegiatan-kegiatan ekonomi yang menunjang kegiatan pendidikan di kawasan ini. Hal tersebut secara pasti turut berperan mendorong peningkatan populasi penduduk di kecamatan ini. Berdasarkan data statistik Kabupaten Sumedang diketahui bahwa Jatinangor merupakan wilayah dengan tingkat kepadatan penduduk tertinggi dengan kepadatan sebesar 4.322 jiwa/ $\mathrm{Km}^{2}$.

Tingkat kepadatan penduduk yang terus meningkat di Kecamatan Jatinangor tersebut telah menyebabkan alih fungsi lahan besar-besaran di kawasan Jatinangor yang berubah menjadi wisma, rumah kos, apartemen untuk pemondokan mahasiswa dan juga pemukiman perumahan. Perkembangan wilayah Jatinangor tersebut telah mendorong terjadinya peningkatan harga tanah yang dipengaruhi oleh semakin sedikitnya lahan terbuka di wilayah 
tersebut yang secara perlahan telah mendorong terjadinya pergeseran ke wilayah yang berdekatan dengan wilayah Jatinangor, dan salah satu wilayah tersebut adalah Kecamatan Cimanggung.

Kemajuan yang terjadi di wilayah Jatinangor ini turut memberikan pengaruh pada wilayah Kecamatan Cimanggung karena saat ini sudah semakin banyak lahan-lahan pertanian yang beralih fungsi menjadi pemukiman perumahan. Ada beberapa faktor yang menjadikan daerah ini terpengaruh kemajuan yang terjadi di Jatinangor tersebut, seperti orbitrasi nya yang relatif dekat, harga tanah yang masih jauh lebih rendah dibandingkan di Kecamatan Jatinangor, dan infrastruktur jalan yang juga semakin baik.

Selain dari faktor perkembangan penduduk yang terjadi di wilayah Jatinangor tersebut, peralihan jumlah penduduk tersebut juga dipengaruhi oleh keberadaan pabrik-pabrik yang terletak di wilayah Kecamatan Jatinangor dan Kecamatan Cimanggung.

Uraian tersebut memperlihatkan bahwa fenomena urban sprawl telah terjadi di wilayah ini. Sehingga dapat dikatakan bahwa urban sprawl tersebut tidak hanya terjadi di wilayah kota-kota besar, tetapi juga terjadi di wilayah-wilayah yang menjadi pusat konsentrasi penduduk seperti di wilayah-wilayah pendidikan, ataupun wilayah industri. Hal tersebut sejalan dengan apa yang dikemukakan oleh Bruegmann (2005: 220) bahwa gejala urban sprawl akan muncul apabila sebuah kota telah mencapai kematangan ekonomi dan tingkat kesejahteraan penduduknya meningkat. Penduduk yang mempunyai kemampuan untuk memilih akan pindah ke luar kota untuk menghindari kemacetan dan polusi di tengah kota, mengurangi biaya-biaya serta mencari wilayah yang lebih luas. Saat ini alasan tersebut bergeser kepada alasan mobilitas, privasi dan pilihan yang lebih banyak tersedia pada wilayah-wilayah yang tersebar. Sedangkan, Glaeser \& Kahn (2003) lebih berfokus pada perkembangan sistem transportasi terutama booming kendaraan bermotor, meningkatnya pendapatan, meningkatnya segregasi sosial serta terbentuknya pasar tanah yang mendorong terbentuknya sprawl.

Tulisan ini secara khusus melihat bagaimana masyarakat petani di desa yang terdampak urban sprawl mengalami proses eksklusi sosial. Tulisan ini akan menguraikan faktor apa saja yang menjadi penyebab terjadinya eksklusi sosial pada masyarakat petani di wilayah desa yang lahanlahan pertaniannya berubah menjadi pemukiman sebagai akibat dari terjadinya pengembangan kota di sekelilingnya. Tulisan ini juga mengemukakan struktur-struktur yang mempengaruhi terjadinya eksklusi sosial pada masyarakat desa. 


\section{METODE PENELITIAN}

Tulisan ini berfokus pada eksklusi sosial yang terjadi pada masyarakat petani dan buruh tani yang lahan pertanian atau lahan garapannya beralih fungsi menjadi pemukiman perumahan di desa Cikahuripan Kecamatan Cimanggung Kabupaten Sumedang. Pemilihan desa Cikahuripan sebagai lokasi studi didasari oleh karakteristik desa yang dalam kurun 2 tahun ini mengalami perkembangan dengan dibangunnya komplek perumahan dilahan-lahan yang sebelumnya merupakan lahan pertanian produktif.

Penulis menggunakan pendekatan kualitatif dengan metode deskriptif. Pemilihan metode deskriptif pada studi ini dilakukan untuk menggambarkan fenomena dan karakteristik masyarakat petani yang mengalami eksklusi sosial. Pengumpulan data primer dilakukan dengan cara observasi, dan wawancara mendalam. Wawancara mendalam ini utamanya dilakukan pada masyarakat petani yang lahan garapannya beralih fungsi menjadi pemukiman perumahan. Wawancara juga dilakukan kepada masyarakat petani yang lahan garapannnya sudah beralih kepemilikan kepada masyarakat dari luar wilayah desa. Informan pada penelitian ini adalah 10 orang petani yang lahan garapannya beralih fungsi mejadi pemukiman perumahan. Wawancara dilakukan untuk mengetahui perubahan yang dialami informan akibat dari berubahnya lahan garapan menjadi pemukiman perumahan tersebut. Aspek-aspek yang menjadi fokus dalam penelitian adalah kemampuan informan mengakses layanan kesehatan, kemampuan informan mengakses layanan pendidikan, kemampuan informan dalam memenuhi kebutuhan ekonomi keluarga, partisipasi sosial, dan perubahan struktur sosial yang terjadi di desa Cikahuripan akibat masuknya kelompok masyarakat baru yang mendiami pemukiman perumahan tersebut. Selain pengumpulan data primer, penelitian ini juga mengumpulkan data sekunder berupa dokumen, hasil penelitian terdahulu, dan arsip-arsip yang dapat menunjang hasil penelitian secara keseluruhan.

\section{KERANGKA TEORITIS}

Giddens (2006:356) mengemukakan bahwa ide mengenai eksklusi sosial pertama kali diperkenalkan oleh para penulis sosiologi untuk merujuk pada sumber-sumber baru ketidaksetaraan. Eksklusi sosial mengacu pada cara-cara di mana individu dapat terputus dari keterlibatan penuh dalam masyarakat yang lebih luas. Misalnya, orang-orang yang tinggal di perumahan yang bobrok, dengan sekolah-sekolah miskin dan sedikit kesempatan bekerja di daerah itu, dapat secara efektif mengalami penolakan dari kesempatan untuk memperbaiki diri yang dimiliki kebanyakan orang di masyarakat. 
Pada masyarakat eropa, akar konsep eksklusi sosial ini tidak bisa dilepaskan dari kemiskinan yang muncul akibat perkembangan industri dimana tidak semua kelompok masyarakat mendapatkan pekerjaan.Eksklusi sosial sering kali dihubungkan dengan underclass yang mana Marx (dalam Giddens, 2006:317) menyebut underclass sebagai lumpenproletariat. Yaitu kumpulan dari orang-orang yang secara persisten berada di luar bentuk-bentuk dominan produksi dan pertukaran ekonomi. Gagasan tersebut selanjutnya semakin berkembang dan diterapkan pula pada kelompok-kelompok orang miskin yang berbahaya, pencuri dan gelandangan yang menolak untuk bekerja dan bertahan hidup dipinggiran masyarakat dan menjadi parasit sosial bagi masyarakat. Kesimpulan dari pemikiran Marx tersebut adalah bahwa eksklusi sosial disebabkan oleh kemiskinan dan underclass.

Serupa dengan itu, Aasland dan Flotten (2000) berpendapat bahwa konsep eksklusi sosial tidak lebih ambigu daripada konsep kemiskinan. Mereka berpendapat bahwa ketika konsep ini pertama kali digunakan di Perancis pada tahun 1970-an, itu memperhitungkan orang-orang yang tidak dapat menyesuaikan diri dengan masyarakat arus utama dan tahun-tahun berikutnya konsep itu sering didefinisikan ulang dan lebih banyak kelompok dimasukkan, seperti anakanak putus sekolah, pemuda pengangguran dan imigran (Aasland and Flotten, 2000: 1027).

Giddens (2006:357) menyebutkan bahwa eksklusi sosial adalah konsep yang lebih luas daripada kemiskinan, meskipun kemiskinan itu sendiri termasuk di dalamnya. Eksklusi sosial memfokuskan perhatian pada berbagai faktor yang mencegah individu atau kelompok dari memiliki peluang dari mayoritas penduduk. David Gordon dan rekan-rekannya (dalam Giddens, 2006:357) membedakan empat dimensi eksklusi sosial: kemiskinan atau eksklusi dari pendapatan atau sumber dayayang memadai; pengecualian atau eksklusi dari pasar tenaga kerja, eksklusi atau pengecualian dari layanan dan eksklusi atau pengecualian dari hubungan sosial.

Merujuk pada uraian mengenai konsep eksklusi sosial tersebut, Lawang (2014:4) menyimpulkan bahwa struktur sosial, ekonomi dan politik turut berperan dalam memunculkan eksklusi sosial dan underclass. Demikian pula halnya dengan eksklusi sosial yang terjadi di Indonesia juga didasarkan pada asumsi tentang struktur sosial dimana eksklusi sosial tersebut terjadi.

Beberapa hipotesis yang dikemukakan oleh Lawang (2014:5-6) mengenai eksklusi sosial di Indonesia diantaranya underclass atau kemiskinan menyebabkan eksklusi sosial; eksklusi sosial di Indonesia bisa menunjuk pada beberapa satuan sosial seperti : fakir miskin, perempuan, orang lanjut usia, orang hidup di daerah terpencil, terkebelakang, penyandang stigma tertentu (komunis, narkoba, HIV Aids, dll.). Mereka ini tidak dapat berpartisipasi dalam kegiatan 
ekonomi sosial politik arus utama; eksklusi sosial daerah perdesaan sudah bersifat struktural, sehingga mempersulit underclass bisa keluar dan sebaliknya orang akan mudah terperosok ke dalamnya.

Adapun Gordon (dalam Giddens, 346-7) menyebutkan empat dimensi eksklusi sosial yaitu kemiskinan atau eksklusi dari pendapatan atau sumber daya yang cukup, eksklusi dari pasar kerja, eksklusi pada bidang pelayanan, dan eksklusi dari relasi sosial

Tulisan ini menguraikan bagaimana perubahan-perubahan yang terjadi pada masyarakat berpengaruh pada perubahan struktur dan selanjutnya mendorong terjadinya eksklusi sosial pada masyarakat petani.

\section{PEMBAHASAN}

\section{Gambaran Wilayah Studi}

Kecamatan Cimanggung merupakan peringkat ketiga kecamatan dengan jumlah populasi penduduk terbesar di Kabupaten Sumedang. Letak kecamatan ini berdampingan dengan Kecamatan Jatinangor yang merupakan kecamatan dengan populasi penduduk terbesar, selain itu kecamatan ini juga berbatasan dengan Kecamatan Tanjungsari.

Jika Kecamatan Jatinangor ditetapkan sebagai kawasan pendidikan tinggi yang termasuk dalam wilayah Metropolitan Bandung Raya berdasarkan pada peraturan daerah Jawa Barat No. 12 Tahun 2014, yang juga diperkuat dengan peraturan daerah Kabupaten Sumedang nomor 2 tahun 2012 tentang rencana tata ruang wilayah Kabupaten Sumedang tahun 2011-2031 disebutkan bahwa; kawasan Jatinangor diarahkan menjadi kawasan pemukiman, termasuk pendidikan tinggi yang mendukung pemantapan kawasan metropolitan bandung raya; pengembangan cyber area dan IPTEK; serta pengembangan pemukiman vertikal dan intensitas pemanfaatan ruang menengah hingga tinggi. Dengan dijadikannya Kecamatan Jatinangor sebagai kawasan Sub Centre atau sub-pusat yang mempunyai fungsi sebagai pembangkit pertumbuhan lokal dan pusat pendidikan dalam penataan Kawasan Metropolitan Bandung. Maka pesatnya perkembangan wilayah Kecamatan Jatinangor yang dipengaruhi oleh keberadaan empat Universitas Ternama di Jawa Barat ini juga telah mendorong pesatnya pertumbuhan ekonomi di wilayah ini, merupakan suatu yang memang sudah direncanakan dan diperhitungkan oleh pemerintah. Saat ini diketahui bahwa laju pertumbuhan penduduk di Kecamatan Jatinangor adalah

Bertumbuhnya wilayah Jatinangor selain telah memberikan pengaruh positif secara ekonomi juga telah berhasil mendorong wilayah-wilayah di sekitarnya turut mengalami perkembangan. 
Salah satu perkembangan yang sangat terlihat adalah semakin banyaknya pemukimanpemukiman baru berupa komplek perumahan yang dibangun diwilayah-wilayah kecamatan disekitarnya, dan salah satu kecamatan tersebut adalah Kecamatan Cimanggung. Hal ini menunjukkan bahwa fenomena urban sprawl juga dialami oleh wilayah yang berdekatan dengan wilayah Jatinangor ini. Bertambah banyaknya pemukiman perumahan tersebut dapat pula dikatakan bahwa lahan-lahan pertanian produktif semakin banyak yang berubah fungsinya.

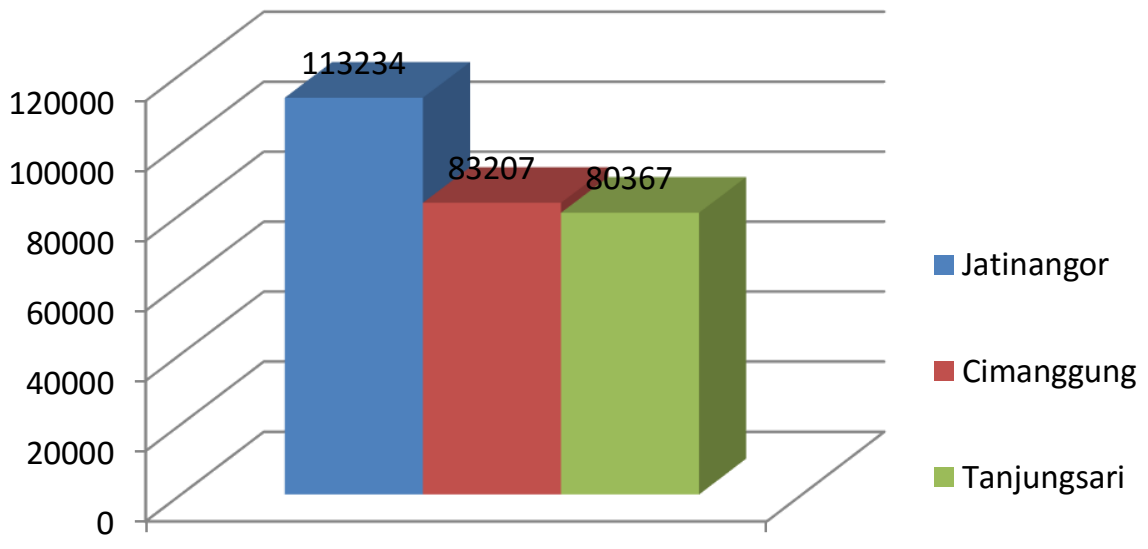

Gambar 1. Kecamatan dengan jumlah penduduk terbesar di Kabupaten Sumedang

Dari 11 desa yang ada di Kecamatan Cimanggung, salah satu desa yang saat ini juga mengalami pertumbuhan dengan adanya pembangunan pemukiman perumahan adalah desa Cikahuripan. Desa ini secara umum didominasi oleh areal pertanian berupa kebun dan ladang. Desa yang terletak di ketinggin $700 \mathrm{mdpl}$ termasuk daerah perbukitan dengan suhu rata-rata $30^{0}-32^{0}$ C. Secara demografis berdasarkan hasil rekapitulasi kependudukan pada tahun 2015 diketahui bahwa jumlah penduduk desa Cikahuripan sebesar 10.251 jiwa yang tersebar dalam 13 rukun warga $(\mathrm{RW})$ dan 50 rukun tetangga $(\mathrm{RT})$.

Sejauh ini perekonomian masyarakat di desa Cikahuripan mayoritas di topang dari sektor pertanian dengan komoditas utama pertaniannya adalah padi sawah, padi ladang, ubi-ubian, talas, buah-buahan, peternakan ikan, ayam, dan kambing. Selain itu di desa Cikahuripan juga berkembang usaha-usaha kerajian, home industry makanan olahan, warung dan toko yang juga sangat menopang perekonomian di desa. 


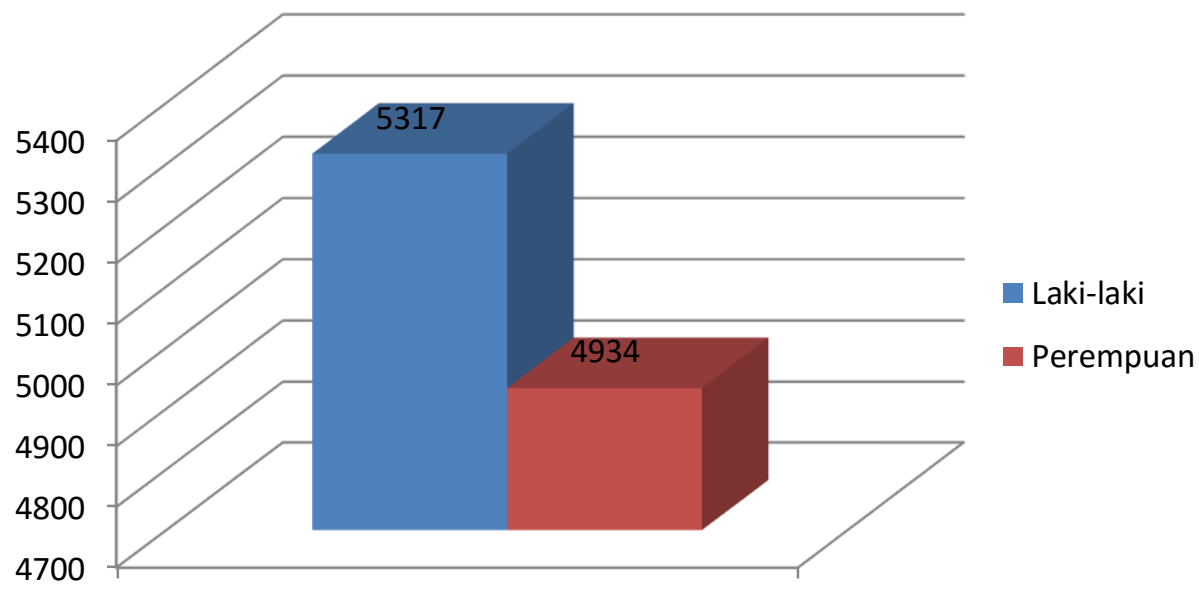

Gambar 2. Komposisi Penduduk Desa Cikahuripan berdasarkan Jenis Kelamin

Selanjutnya, jika dilihat dari pekerjaan, masyarakat yang tidak bekerja jumlahnya paling besar jika dibandingkan dengan masyarakat yang berprofesi sebagai petani, pedagang, buruh pabrik, tukang, buruh bangunan, tukang ojek, buruh industri rumah tangga dan lainnya. Untuk lebih jelas dapat dilihat pada grafik berikut ini:

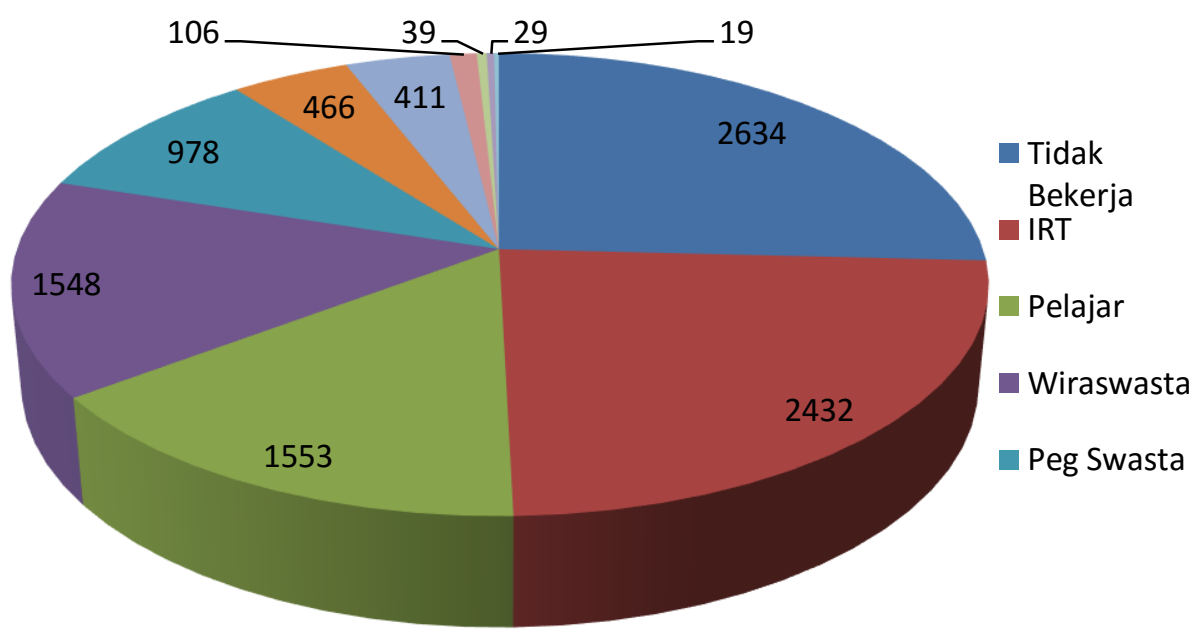

\section{Gambar 3. Komposisi Penduduk Desa Cikahuripan berdasarkan Jenis Pekerjaan}

Grafik tersebut memperlihatkan bahwa dari komposisi penduduk yang ada tersebut secara jelas dapat dikatakan bahwa 65\% warga masyarakat di desa ini tidak bekerja, dimana jika melihat pada data penduduk berdasarkan kelompok usia dapat dilihat bahwa jumlah penduduk yang masuk kategori usia produktif adalah sebesar 69\%. Adapun pilihan pekerjaan masyarakat 
yang banyak bekerja disektor informal lebih disebabkan oleh tingkat pendidikan yang rendah. Sedangkan untuk masuk bekerja sebagai buruh di pabrik-pabrik yang tersebar di wilayah Kecamatan Cimanggung ini ijazah pendidikan tidaklah menjadi prasyarat untuk diterima bekerja. Adanya jaringan broker/calo untuk dapat diterima kerja di pabrik-pabrik tersebut telah membentuk dan disisi lain juga telah mendorong masyarakat untuk tidak menjadikan sekolah sebagai prioritas yang penting.

Penelitian ini mengungkap bahwa anak-anak usia sekolah di Desa Cikahuripan mayoritas hanya menamatkan pendidikan SMP dimana setelah tamat SMP sebagian besar anak-anak ini mulai bekerja di sektor-sektor informal. Adapun bagi anak perempuan, sebagian besar tidak bekerja hingga berusia 18 tahun untuk dapat bekerja di pabrik-pabrik yang ada dengan memalsukan ijazah dan masuk melalui calo dengan membayar uang 4 hingga 8 juta rupiah.

Untuk dapat bekerja sebagai buruh di pabrik masyarakat biasanya menjual barang berharga yang mereka miliki, dengan harapan setelah masuk bekerja dapat diganti secara mencicil. Beberapa kasus juga menunjukkan bahwa untuk dapat mempekerjakan anak-anaknya di pabrik, orang tua rela menjual tanah yang menjadi sumber pendapatannya sebagai petani. Dengan gambaran kondisi sosial semacam ini, dan melihat fakta bahwa perkembangan yang terjadi di kecamatan jatinangor yang letaknya berdampingan akan terus bertumbuh dan diproyeksikan akan menjadi kota metropolitan dalam beberapa tahun kedepan, dan fakta bahwa saat ini di kecamatan Cimanggung yang berdampingan dengan kecamatan jatinangor telah banyak dibangun pemukiman perumahan baru, menunjukkan bahwa urban sprawl itu terjadi.

Disisi lain, tingginya jumlah warga masyarakat yang tidak bekerja, dan semakin berkurangnya jumlah masyarakat yang berprofesi sebagai petani juga menjadi bukti bahwa semakin banyak lahan-lahan pertanian yang beralih fungsi menjadi pemukiman. Sementara itu, kualitas pendidikan di masyarakat juga masih rendah sehingga sangat memungkinkan bagi masyarakat yang ada di desa Cikahuripan ini untuk terjebak kedalam eksklusi sosial.

\section{Faktor-Faktor yang Mempengaruhi Perubahan Di Desa Cikahuripan}

Perkembangan wilayah Jatinangor yang pesat dan semakin padat telah memberikan pengaruh kepada wilayah-wilayah disekitarnya, Kecamatan Cimanggung tepatnya wilayah desa Cikahuripan tak luput dari pengaruh tersebut. desa yang dikenal sebagai wilayah pertanian ini saat ini juga mengalami perubahan secara perlahan dengan adanya beberapa perumahan yang dibangun di wilayah desa ini. Konsekuensi dari pembangunan perumahan tersebut adalah banyak lahan pertanian produktif yang berubah fungsi. 
Hasil penelitian memperlihatkan bahwa jauh sebelum terbangunnya perumahan di wilayah desa ini, diketahui bahwa banyak tanah-tanah pertanian produktif yang ada diwilayah desa ini sudah tidak dimiliki oleh warga di desa ini. Lahan-lahan pertanian produktif tersebut sudah berpindah kepemilikan pada orang-orang yang tinggal di kota bandung. Perpindahan kepemilikan tanah tersebut menempatkan petani hanya menjadi penggarap dimana hasil panen juga harus dibagi hasil dengan pemilik lahan tersebut sehingga membuat masyarakat petani sebagai penggarap pendapatannya semakin berkurang.

Perkembangan desa dengan adanya perumahan secara otomatis mendorong desa semakin terbuka dengan adanya penduduk pendatang, dimana secara karakter berbeda dari masyarakat desa. Perbedaan tersebut dapat dilihat pada beberapa hal seperti pekerjaan, etnis, tingkat pendidikan dan tingkat kesejahteraan. Dengan adanya perbedaan-perbedaan tersebut terlihat adanya pemisahan dalam masyarakat dengan istilah "orang perum" dan "orang kampung". Selanjutnya, adanya pemukiman perumahan tersebut juga berpengaruh pada meningkatnya harga tanah di desa ini yang akhirnya juga turut mendorong semakin banyak lahan-lahan pertanian produktif yang ada di desa dijual oleh masyarakat. Hal ini berdampak pada masyarakat yang berprofesi sebagai penggarap, karena tanah garapan dijual oleh pemiliknya maka penggarap ini tidak bisa lagi menjadi penggarap dan akhirnya kehilangan pekerjaan atau beralih profesi menjadi buruh tani yang penghasilannya semakin menurun karena tidak adanya kepastian pekerjaan yang akan didapat setiap harinya.

Keberadaan 22 pabrik disekitar wilayah desa seharusnya dapat membuka kesempatan bagi masyarakat untuk bekerja. Namun realitasnya tidak semua warga usia produktif dapat diterima kerja di pabrik-pabrik tersebut fakta menunjukkan masyarakat yang bekerja di pabrik jumlahnya tidak lebih dari 3\%. beberapa hal menjadi kendala bagi masyarakat diantaranya adalah; kemiskinan masyarakat (menyebabkan masyarakat tidak mampu membayar untuk masuk kerja, (untuk masuk kerja harus melewati calo dan harus membayar uang pelicin yang besarannya 4-8 juta), tingkat pendidikan masyarakat yang rendah (menyebabkan semakin terbatasnya pilihan pekerjaan yang dapat diakses masyarakat) untuk dapat diterima kerja di pabrik beberapa kasus menunjukkan bahwa terjadi pemalsuan ijazah, ada previlege untuk masyarakat keturunan Tionghoa dimana ketika masuk bekerja langsung menjadi karyawan dengan jabatan sebagai mandor terutama di PT Kahatek (menyebabkan munculnya rasa superioritas pada etnis Tionghoa yang jika diperuncing akan menjadi konflik laten).

Selanjutnya, ada dana pembangunan yang dikucurkan pemerintah langsung ke desa juga berpengaruh pada semakin terbukanya akses ke desa sehingga wilayah desa menjadi semakin terbuka sehingga terjadinya perpindahan masyarakat ke wilayah-wilayah desa semakin besar. 
Selain itu, tidak adanya kesamaan cetak biru rencana pembangunan di tiap-tiap desa menyebabkan desa terjebak pada pembangunan infrastruktur fisik saja, sehingga peralihan kepemilikan lahan-lahan pertanian produktif di desa menjadi tidak terhindarkan.

\section{Eksklusi Sosial pada Masyarakat Petani}

Dari beberapa faktor yang diuraikan tersebut dapat dijabarkan beberapa hal yang menjadi pendorong terjadinya eksklusi sosial pada masyarakat petani di desa. Pertama, pesatnya pembangunan yang terjadi di wilayah Jatinangor telah mendorong peningkatan harga tanah di wilayah ini, sehingga berdampak pada terjadinya pengembangan pemukiman perumahan ke wilayah yang berdekatan dengan wilayah ini. Hal tersebut berdampak pada terjadinya alih fungsi lahan pertanian yang menyebabkan terjadinya perubahan mata pencaharian pada masyarakat yang tadinya merupakan petani, menjadi penggarap dan buruh tani.

Perubahan mata mencaharian tersebut berdampak pada terjadinya ketidakpastian pendapatan dan juga telah memunculkan ketergantungan petani penggarap dan buruh tani pada pemilik lahan. Hal tersebut pada akhirnya mendorong masyarakat menjadi semakin miskin.

Kemiskinan masyarakat petani dengan tingkat pendidikan dan kesadaran pendidikan yang rendah menyebabkan banyak anak-anak usia sekolah yang putus sekolah. Dampak dari hal tersebut adalah sulitnya anak-anak usia produktif untuk mendapatkan pekerjaan yang layak. Hal tersebut telah mendorong meningkatknya kasus-kasus pencurian di desa, disisi lain juga telah mendorong berkembangnya premanisme.

Kemiskinan yang dialami oleh masyarakat petani tersebut juga telah menyebabkan masyarakat kesulitan untuk mengakses layanan kesehatan. Meskipun pemerintah telah memberikan kemudahan bagi masyarakat miskin untuk mendapatkan layanan kesehatan melalui program kartu indonesia sehat (KIS), tidak semua masyarakat petani yang memanfaatkan layanan tersebut karena adanya ketakutan untuk membayar iuran bulanan ketika memanfaatkan kartu indonesia sehat tersebut. Beberapa informan mengemukakan bahwa mereka lebih memilih melakukan pengobatan sendiri dengan membeli obat warung atau meminun ramuan-ramuan tradisional. Beberapa kasus yang ditemukan di desa tidak jarang karena keengganan untuk berobat di pusat layanan kesehatan akhirnya berujung pada kematian karena tidak diketahuinya penyakit.

Selanjutnya, pada konteks pekerjaan terkait dengan keberadaan pabrik-pabrik yang ada di sekitar wilayah desa. Tingkat pendidikan yang rendah, dan berkembangnya praktik percaloan untuk dapat masuk bekerja di pabrik telah menyebabkan banyak masyarakat yang memiliki tanah atau lahan menjual lahannya untuk memasukkan anak-anak mereka bekerja, sedangkan 
pada masyarakat yang tidak memiliki lahan terpaksa berhutang pada rentenir yang akan dibayar secara mencicil ketika anaknya telah masuk bekerja di pabrik-pabrik tersebut.

Dinamika sosial ekonomi yang terjadi pada masyarakat petani di desa Cikahuripan tersebut memperlihatkan bahwa eksklusi sosial yang terjadi dipengaruhi oleh faktor-faktor eksternal dan internal. Mengacu pada analisis yang dikemukakan oleh Gordon (dalam Giddens, 346-7) yang membedakan empat dimensi eksklusi sosial. Maka dapat dilihat bahwa eksklusi sosial masyarakat petani di desa Cikahuripan dari memperoleh pendapatan yang memadai disebabkan oleh menghilangnya sumber-sumber pendapatan mereka karena adanya alih fungsi lahan pertanian yang mendorong mereka menjadi petani penggarap atau buruh tani sehingga menyebabkan mereka menjadi termiskinkan. Selanjutnya pada pasar tenaga kerja, rendahnya tingkat pendidikan dan kemiskinan menyebabkan masyarakat tidak dapat mengakses pekerjaan dipabrik-pabrik yang ada disekitar lingkungan mereka, hal tersebut juga mendorong meningkatnya kasus-kasus pencurian di desa, yang menyebabkan kehilangan materi dan mendorong masyarakat masuk semakin jauh dalam kemiskinan. Kemiskinan juga menyebabkan masyarakat enggan mengakses layanan kesehatan. Kemiskinan juga berpotensi mendorong munculnya ketimpangan struktur karena tidak terjadinya integrasi antara masyarakat tempatan dan pendatang. Hal ini sejak awal terlihat dengan adanya pelabelan pribumi dan pendatang, yang menyebabkan dua struktur ini tidak terintegrasi secara baik. Hal ini menyebabkan budaya kemiskinan terus terjadi pada masyarakat tempatan.

\section{KESIMPULAN}

Berdasarkan pada uraian yang dikemukakan tersebut beberapa hal yang dapat disimpulkan diantaranya adalah sebagai berikut:

1) Pesatnya pertumbuhan wilayah Jatinangor yang berkembang menjadi metropolitan telah mendorong turut berkembangnya wilayah-wilayah disekitarnya yang ditandai dengan bertumbuhnya pemukiman-pemukiman baru. Pertumbuhan pemukiman baru tersebut telah mendorong alih fungsi lahan yang menyebabkan terjadinya perubahan mata pencaharian pada masyarakat petani.

2) Perubahan mata pencaharian masyarakat petani ini telah mendorong ketidakpastian pendapatan dan menyebabkan kemiskinan, yang dengan kondisi itu telah mendorong keluarga petani kesulitan untuk mendapatkan pekerjaan di pabrik-pabrik disekitar wilayah desa, dan enggan mendatangi layanan kesehatan ketika menderita sakit.

3) Pengucuran dana desa di desa Cikahuripan yang lebih diarahkan pada pembangunan infrastruktur fisik justru semakin mendorong terbukanya akses yang menyebabkan 
meningkatnya harga tanah dan semakin banyak lahan-lahan pertanian produktif yang dijual oleh masyarakat. Bagi masyarakat yang memiliki lahan hal tersebut akan menguntungkan mereka karena dapat membeli lahan ditempat-tempat lain untuk bertani, namun bagi masyarakat yang menjadi petani penggarap dan buruh tani peralihan kepemilikan lahan pertanian tersebut berarti hilangnya mata pencaharian yang menyebabkan mereka tidak berpotensi masuk semakin jauh dalam kemiskinan.

\section{DAFTAR PUSTAKA}

Apriani, Vina Indah dan Asnawi. 2015. Tipologi tingkat Urban Sprawl di Kota Semarang. Jurnal Teknik PWK Volume 4 Nomor 32015.

BPS Kabupaten Sumedang. 2017. Kabupaten Sumedang dalam Angka

Gallie, Duncan. 2004. Resisting Marginalization: Unemployment Experience and Social Policy in the European Union. Oxford. UK

Gerda Jehoel-Gijsbers and Cok Vrooman. 2007. Explaining Social ExclusionA theoretical model tested in the Netherlands. The Netherlands Institute for Social Research/scp. The Hague

Giddens, Anthony. 2006. Sociology $5^{\text {th }}$ Edition. Polity Press. UK

Jane Mathieson, et al. 2008. Social Exclusion Meaning, measurement and experience and links to health inequalities A review ofliterature. WHO Social Exclusion Knowledge Network Background Paper 1. Social exclusion literature review September 08

Lawang, Robert M.Z. 2014. Beberapa Hipotesis Tentang Eksklusi Sosial di Indonesia. Jurnal Imu Sosial Mamangan, Nomor 2. Volume I. Tahun 2014 